\title{
Pollerdrähte zum Führen von eingeschobenen MIPO-Platten
}

Dankward Höntzsch

Eingeschobene Platten machen manchmal nicht das, was wir wollen.

Sie fangen an, die Mittellinie zu verlassen, oder der eingeschobene Anfang droht nach ventral oder dorsal abzurutschen, wenn die Platte ganz eingeschoben ist.

„Pollerdrähte“ ( $\triangleright$ Abb. 1 und 2) können sehr gut helfen und sind ganz einfach, ohne Aufwand und ohne Komplikationsgefahr einzusetzen. Am Schaft, wo die Platte nicht abweichen soll, einfach über eine nur angestochene Stichinzision einen Kirschner-Draht platzieren ( $\bullet$ Abb. 1). Dann kann die Platte wie von einer Leitplanke geführt werden und bleibt in der Mittellinie. Ein Pollerdraht im Bereich des Einschiebens kann verhindern, dass am Ende die Platte nach dorsal oder ventral rutscht ( $\vee$ Abb. 2).

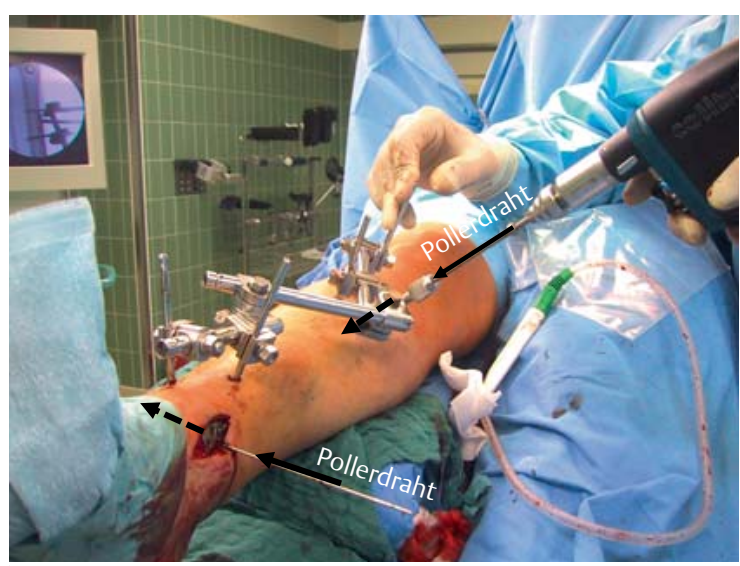

- Abb. 1 Ein ventral am Tibiaschaft eingebrachter Kirschner-Draht führt die eingeschobene Platte in der Mittellinie und verhindert die drohende Abweichung nach ventral.
Die Positionierung des Drahtes ist je nach drohender Abweichung zu wählen und kann in vielen Fällen von Nutzen sein.

\section{Korrespondenzadresse}

Prof. Dr. Dankward Höntzsch

hoentzsch@t-online.de

Bibliografie

DOI https://doi.org/10.1055/a-0946-6272

OP-JOURNAL 2019; 35: 189 @ Georg Thieme Verlag KG Stuttgart · New York ISSN 0178-1715

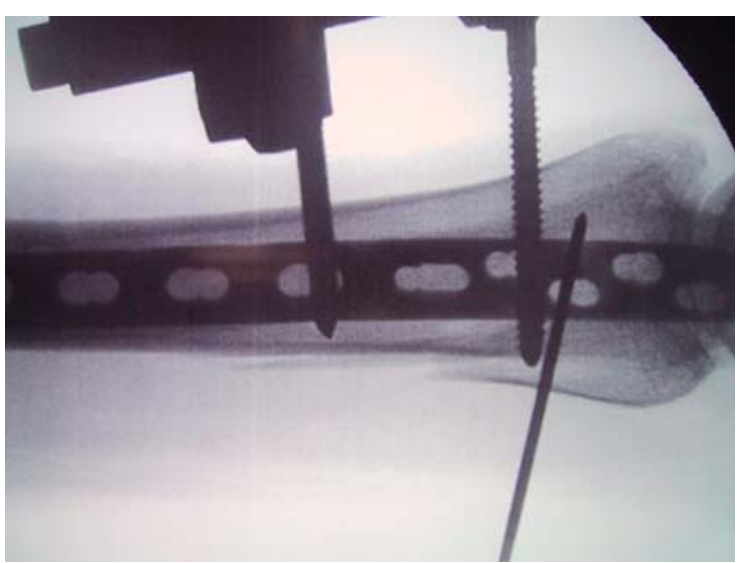

Abb. 2 Ein Kirschner-Draht verhindert, dass das Plattenende im Inzisionsbereich an der distalen Tibia zu weit nach hinten rutscht. 